January 2014

\title{
Using Culturally Ambitious Teaching Practices to Support Urban Mathematics Teaching and Learning
}

Lanette R. Waddell

Vanderbilt University, Iwteach14@gmail.com

Follow this and additional works at: https://digitalscholarship.unlv.edu/jpme

\section{Repository Citation}

Waddell, Lanette R. (2014) "Using Culturally Ambitious Teaching Practices to Support Urban Mathematics Teaching and Learning," Journal of Praxis in Multicultural Education: Vol. 8: No. 2, Article 2.

DOI: 10.9741/2161-2978.1069

Available at: https://digitalscholarship.unlv.edu/jpme/vol8/iss2/2

This Article is protected by copyright and/or related rights. It has been brought to you by Digital Scholarship@UNLV with permission from the rights-holder(s). You are free to use this Article in any way that is permitted by the copyright and related rights legislation that applies to your use. For other uses you need to obtain permission from the rights-holder(s) directly, unless additional rights are indicated by a Creative Commons license in the record and/ or on the work itself.

This Article has been accepted for inclusion in Journal of Praxis in Multicultural Education by an authorized administrator of Digital Scholarship@UNLV. For more information, please contact digitalscholarship@unlv.edu. 


\section{Using Culturally Ambitious Teaching Practices to Support Urban Mathematics Teaching and Learning}

Urban middle and high schools, though challenging places to work, can also be gardens of innovation and creativity for the students and teachers who work in them. How urban school districts support and enhance the educational preparation of their teachers is of paramount importance to the learning of the students who attend these schools. Culturally relevant pedagogy (CRP) is a set of principles that has been shown to support teaching in urban and high poverty settings (Howard, 2001; Lipman, 1995; Morrison, Robbins, Rose, 2008). Its basic tenets - academic achievement, cultural competence, and critical consciousness - address many of the issues urban teachers face in developing a positive and productive classroom environment (Ladson-Billings, 1994). However, as a pedagogy, CRP has not become a staple in many classrooms and schools across the country as research on CRP has not provided specific practices for teachers to employ (Ladson-Billings, 2006) nor has research on CRP clearly delineated how student achievement broadly or narrowly defined - correlates to a CRP ideological stance.

The field of mathematics education would be a good test case for operationalizing CRP. Math has long been a gatekeeper for course taking, college acceptance and success, and college-major choices (Moses \& Cobb, 2001; Schoenfeld, 2002). With the societal view that anyone good at math is intellectually superior, those good at math tend to be White males or Asian, and that mathematics is culture free, it is imperative to provide a counter-narrative about what math is and how it can be taught so all students can succeed (Anderson, 1990; Burton, 1994; Rosa \& Orey, 2010). This work will advance a set of teaching practices in mathematics for urban teachers, called Culturally Ambitious Teaching Practices in mathematics (CATP), that considers the possibilities of developing academically challenging yet welcoming classrooms for all students. Specifically, this work will address the following questions:

1. In what ways can the theory of culturally relevant pedagogy be operationalized into teachable and observable ambitious mathematics teaching practices?

2. What areas of CATP are readily observable? Which areas were difficult to observe consistently?

3. How will ratings from the CATP instrument define successful and nonsuccessful implementation of CATP?

\section{Defining urban}

Before I begin, it is important to define what urban is in the context of this work. In the New Oxford American Dictionary (2009), urban has two distinct 
definitions: 1) relating to the characteristics of a city or town (high population density, economic and cultural diversity) and 2) denoting popular black culture. This connection of urban with African American culture denotes a vibrant, creative, and rich history of a cultural group connected to city living. We know, however, that urban spaces also include economic and cultural diversity that goes beyond just the African American cultural or ethnic group. For this work, I define urban students as students of multiple ethnic backgrounds who dwell in cities and bring their cultural, ethnic, socio-economic, and familial diversity to the city schools they attend. As such, the idea of what it means to attend to issues in urban schools requires a thoughtful consideration of all the cultures that come together in a school and how schools work toward infusing and embracing this diversity.

\section{Review of Literature}

\section{Understanding Culturally Relevant Pedagogy}

Culturally relevant pedagogy was originally described by Gloria Ladson Billings (1994) in her study of eight African American teachers who were considered to be excellent teachers of students of color. Drawing on critical race theory, she defined CRP as "a pedagogy that empowers students intellectually, socially, emotionally, and politically by using cultural referents to impart knowledge, skills, and attitudes" (p. 18). CRP rests on three main ideals: academic achievement teachers demand, reinforce, and produce academic excellence in their students; cultural competence - students maintain cultural integrity in their academic excellence; and critical consciousness - students are expected to engage the world and others critically (Ladson-Billings, 1995). These areas are three crucial interconnected spaces in a pedagogy of opposition and collective empowerment (Ladson-Billings, 2006). However, culturally relevant pedagogy continues to stay in the margins of educational research and with limited enactment in classrooms. Sleeter (2010), in her work on issues confronting the implementation and marginalization of culturally relevant pedagogy in research and practices, posited that because of the current trend in educational reforms, CRP has not been taken seriously and its power not fully researched or harnessed. Moreover, she argued that other factors have added to CRP's marginalization: a persistence of simplistic conceptions of what CRP is, such as cultural celebration, trivialization, and essentializing; little CRP research on a large scale that connects CRP practices to student achievement; CRP research that only speaks to specific contexts (ethnicities); and the fear of politicizing the classroom through CRP tenets. She suggested clearly defining what CPR is and what it looks like in classrooms while cutting through the political turmoil to highlight how CRP challenges "unjust social relations" (pg. 23). 
In research on culturally relevant teaching practices, the three prongs of CRP - academic achievement, cultural competence, and critical consciousness were rarely found together. Most research on CRP focused on cultural competence; looking closely at students' cultural habits, behaviors, and choices in order to infuse them into teaching practices and curriculum materials (Benson, 2003; Enyedy \& Mukhopadhyay, 2007; Hastie, Martin, \& Buchanan, 2006; Hefflin, 2002; Young, 2010). Less attention was placed on academic achievement, and least of all, critical consciousness. Young (2010) in her study on supporting school administrators and teachers in implementing CRP practices, found teachers were less likely to address issues of social justice with curriculum materials or events. In their literature review of 45 studies describing culturally relevant pedagogy, Morrison, Robbins, and Rose (2008) also found fewest examples of critical consciousness being enacted in CRP classrooms. Young (2010) provided an explanation for this lack of consideration of critical consciousness; teachers can have "an unintended cultural bias or an unpreparedness to confront issues that are racially and socially charged" (p. 256).

\section{Culturally relevant pedagogy and mathematics teaching}

Understanding and navigating the pathways that lead to academic success are crucial in mathematics. Studies have shown that mathematics school achievement is affected more by the school environment (i.e. curriculum, teacher qualifications and expectations, materials) than by the home environment (Lee, 1998; Roscigno, 1998); that mathematics is critical in advancing to higher education due to its filtering effect (Schoenfeld, 2002); and that mathematics is a civil rights issue in that if children are not math literate they will be doomed to second-class economic status (Moses \& Cobb, 2001). As many urban students of color perform poorly in math on classroom achievement and standardized tests, it is imperative to look beyond students' backgrounds as the sole reason for their difficulties and consider how mathematics is taught in schools.

Ethnomathematics - the study of the relationship between culture and mathematics - considers how different cultures use mathematics to solve problems (D’Ambrosio, 2001; Rosa \& Orey, 2010). An ideological framework behind ethnomathematics is that "mathematics is a cultural product and that every culture has developed its own form of mathematics"(Rosa \& Orey, 2010, p. 21). As defined, ethnomathematics shares a vision of teaching and learning with culturally relevant pedagogy in that "the teacher builds from the students' knowledge (ethno) or informal mathematics and orients the lesson toward their culture and experiences (mathema), while developing the students' critical thinking skills" (p. 24). If we are serious about creating equitable classrooms where all students have opportunities to learn math at high levels, considering the 
influence culture has on the math knowledge being shared with students as well as the impact culture has on how math knowledge is learned by students leads us to focus on the cultural influences teachers draw on to understand and impart math knowledge in their classrooms.

In the studies that focused on culturally relevant teaching in mathematics classrooms, a consistent finding is the use of student prior knowledge, both cultural as well as mathematical, in classroom practice (Brenner, 1998; Bonner, 2009; Gutstein, Lipman, Hernandez, \& de los Reyes, 1997; Matthews, 2003; Nasir, 2002; Osisioma, kiluva-ndunda, \& Van Sickle, 2008; Tate, 1995). Matthews (2003) suggested teachers should work to form a dialectical relationship among themselves, their students, and the community such that informal/cultural knowledge and critical thinking be used to build bridges to culturally accepted mathematics knowledge and the culture of school. Gutierrez (2009) also contended that to move toward equitable mathematics teaching, teachers must know their students through a variety of avenues - academically, socially, personally - without essentializing who they are. Creating equitable classrooms where all students have opportunities to learn math at high levels, we must consider the influence culture has on the math knowledge being shared with students as well as the impact culture has on how math knowledge is learned by students.

Other findings in the research on culturally relevant mathematics teaching demonstrated how teachers made connections to students' lives and communities with real world applications of mathematics (Ensign, 2003; Enyedy \& Mukhopadhyay, 2007; Gutstein, Lipman, Hernandez, de los Reyes, 1997; Rosa \& Orey, 2010; Tate, 1995). It is crucial for students to grapple with the messiness and unpredictability of the real world through applications with direct connections to students' lives. However, because students bring different experiences, habits, and values with them to a classroom, trying to account for those myriad experiences can be an impossible and overwhelming task for teachers. It then becomes important to develop a critical and problematic stance about teaching and learning school mathematics as a way to bring the messiness found in real life applications to the abstract work of school mathematics.

\section{Ambitious and High Leverage Mathematics Teaching Practices}

Ambitious and high leverage mathematics teaching practices have been studied in mathematics teacher education; its focus has mainly been on how novice teachers learn high level and critical mathematical practices (Ball \& Forzani, 2009; Grossman, Hammerness \& McDonald, 2009; Lampert, Boerst, \& Graziani, 2011). However, ambitious math practices are just as important for in-service teachers. Lampert, Boerst, Graziani (2011) defined ambitious teaching as "teaching that 
aims to teach all kinds of students to not only know academic subjects, but also to be able to use what they know in working on authentic problems in academic domains" (p. 1, emphasis added). High leverage teaching practices are "teaching practices in which the proficient enactment by the teacher is likely to lead to comparatively large advances in student learning" (Ball, Sleep, Boerst, \& Bass, 2009 , p. 460). High leverage and ambitious teaching practices (see figure 1) in math focus on what learning is co-produced by teachers and students in specific contexts, what practices are central to daily math teaching, and considers student differences and issues of equity (Ball, 2011).

\section{Figure 1}

High leverage teaching practices adapted from Ball (2011), "Supporting High-Quality Mathematics Instruction"

Ten high leverage practices for ambitious math learning

- choosing math tasks that are complex and build skills

- choosing examples

- academic language

- productive whole-class discussions

- reflecting on and using student errors

- using homework equitably

- specific math focused positive reinforcement

- public recordings

- diagnosing patterns of student thinking

- assessing and adapting to students' math proficiencies

However, since most of the research has been on supporting the development of novice teachers, less focus has been paid to in-service teachers and the kinds of classroom environments that support ambitious math practices. This work considers how ambitious mathematics teaching practices can embrace ideals of culturally relevant pedagogy in order to develop such a classroom environment: addressing cultural competence through building on and to students' prior knowledge, encouraging academic achievement through the development of inquiry skills, and infusing critical consciousness by adopting a problematic stance about mathematical ideas and content.

\section{Culturally Ambitious Teaching Practices in Mathematics}

I define Culturally Ambitious Teaching Practices in Mathematics (CATP) as mathematics teaching practices that support the development of a culturally relevant classroom environment and is a space for learning ambitious mathematics through a community of teachers and schools leaders who critically reflect on teaching. Appendix A provides the list of practices in rubric form, defined and organized by CRP tenets. CATP is a framework that meshes the 
ideals of cultural relevance with the ideals of ambitious mathematics into a set of teaching practices that are used to develop a classroom environment in which all students, but particularly urban students, can achieve and learn mathematics at a high level. Why classroom environment? I posit that the starting point for implementing CRP is the classroom environment; students need to consider how they fit into the classroom community and how they can have an impact on the learning environment. Teachers also have to consider how they themselves fit into the classroom environment they are crafting - thinking about their own beliefs, culture, and learning habits and how these beliefs and habits interact with their teaching practices. As such, the demands on teachers is to understand not only the mathematical knowledge in the work they do, but also to include the multiple perspectives of students and their habits of interaction. It is the teacher's work to build a classroom environment that supports the mathematical knowledge to be taught, the cultures students bring, and the practices that acknowledge, examine, and support student growth as math learners. Doing high-level mathematics through critical analysis with your peers, taking risks and making mistakes, or engaging in discussions that draw on different, and sometimes uncomfortable, worldviews requires students to be in a space where they feel safe and cared for. Developing that environment then becomes structure upon which culturally relevant pedagogy and ambitious math can find a foothold.

Drawing on the work of Tompkins (2009) on the development of a classroom community in language arts classrooms and Matsumura, Slater, and Crosson's (2008) work on classroom climate and rigorous instruction in urban schools, I define a classroom environment as having three parts. First is the learning environment, which encompasses the structures and procedures that support student learning and the academic attitudes developed in the classroom. Another aspect of the environment is the classroom community that considers the interactions between community members and the supportive relationship for learning that can be developed among those members. Finally, the classroom climate is the degree to which students feel safe and supported in the classroom and how that safety allows students to critically consider their world (see figure 2 ).

\section{Learning environment}

The learning environment has as its focus the CRP tenet of academic achievement. Teachers demand, reinforce, and produce academic excellence in their students; students' skills and abilities are valued and channeled in academically important ways (Ladson-Billings, 1995). Providing structures, templates and academic protocols for students allows them to have a base upon which to build their learning and in turn, will scaffold students to tackle higher-level problems and tasks. Teachers also know that in order for students to be successful in the work 
that is expected of them, additional work may be needed on a regular basis - in and out of the classroom. Students need multiple opportunities to learn new materials, review areas of academic weakness, and grapple with challenging ideas while developing perseverance and dedication for their academic endeavors.

Figure 2

The development of culturally ambitious teaching practices in mathematics

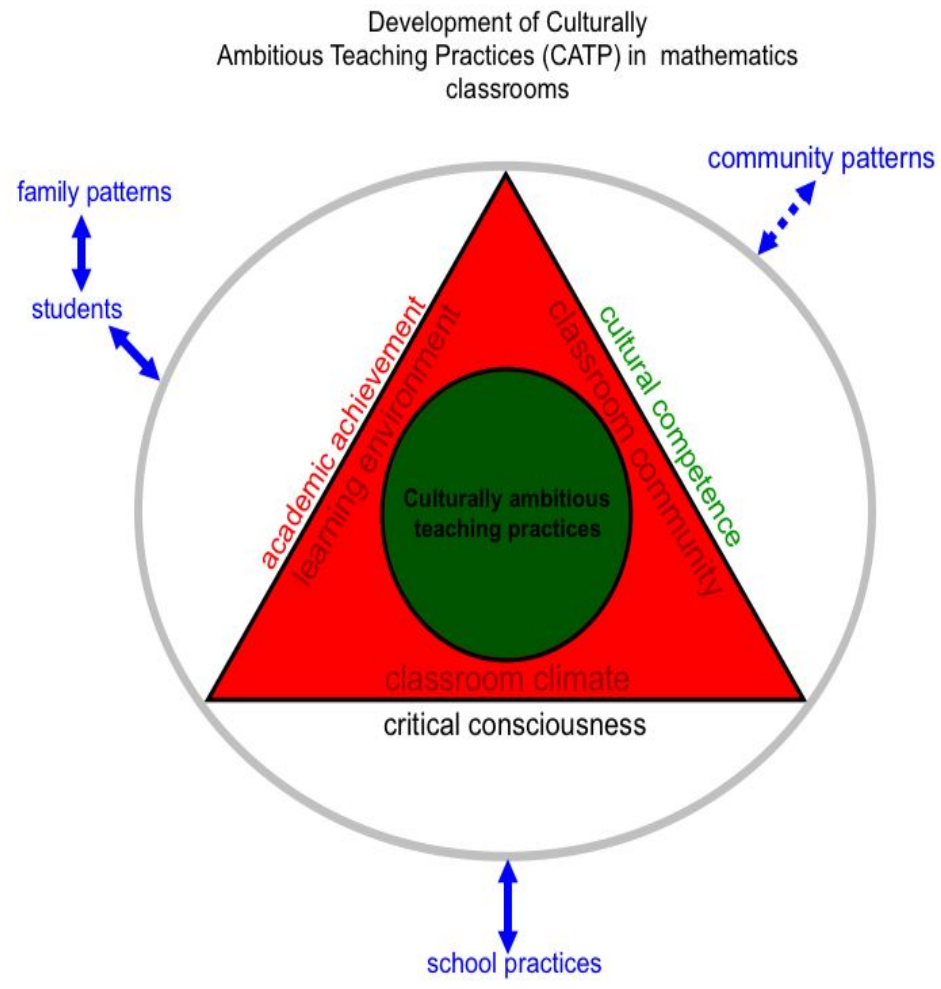

\section{Classroom community}

By paying close attention to the classroom community, teachers utilize students' cultural competence as a vehicle for learning; students maintain their cultural integrity as they strive for academic excellence. Classroom communities are designed to enhance cultural competence encourage students to be self-reflective about their multiple identities and how those identities can be used to create a positive life path. However, many middle and high school students are aware of the expected school behaviors, rules, and protocols but may enact behaviors that are deemed "unacceptable" in a school setting. In particular, many urban students 
come to school with ideals and habits that do not match "mainstream" ways of interacting in school. Though some behaviors may be detrimental to students' academic learning, other behaviors that are deemed unacceptable could be parts of the cultural habits and histories of the students' lives. Teachers can support students' cultural competence by critiquing their responses to behaviors and determining the detriment and/or benefit to learning each behavior represents and then responding accordingly (Davis and Martin, 2008). Knowing each student academically, socially, and personally supports a teacher's ability to further understand student behaviors.

\section{Classroom climate}

To engage in a critical consciousness stance about learning, the classroom climate must allow students to feel safe. Developing a safe classroom means teachers readily address issues and events that can potentially make students fearful and hesitant in their interactions with others. Through a safe classroom climate, teachers and students can examine inequities in society and how these inequities play out in their lives. In order to consider and understand the ways in which societal biases impact policies, rules, and structures, students will need to develop a critical or problematic stance for trying to uncover such biases. A problematic stance means you consider things from a critical or questioning point of view (Hiebert et al., 1997). This problematic stance, however, does not only have to be used when thinking of issues in society and community. This also includes ideas such as basic algorithms in math as well as reasons for war in social studies. Asking why we learn certain algorithms or whose viewpoints the reasons for war are supported and whose viewpoints are rejected denote viewing school learning in a problematic way. Developing a problematic stance in relation to everyday school learning is important, as it develops the skill of critical inquiry in students that includes querying issues and ideas both in and out of school.

\section{Outside Factors}

Although teachers hold a great degree of autonomy and responsibility in developing their classroom environments, there are other factors that influence the classroom and the practices teachers put into place. Families and students have a large impact on the structures and procedures that support learning in the classroom. As discussed previously, the habits and practices students learn from their families can interact in a classroom in multiple ways; teachers need to be aware and open to any conflicts or differences. School policies and practices can also have an impact on the teaching practices implemented in a classroom. Being flexible, staying involved in policy and committee decisions at the school and/or 
district level, and maintaining open lines of communication with school leadership will allow teachers to become an advocate for culturally relevant and ambitious teaching as an important staple in their school. Finally, the community in which the school is situated, too, can have an impact on how teachers develop their classroom environment. Knowing and drawing on available community services can bring a variety of opportunities to a school and classroom. The development of a classroom designed to support students in critical inquiry about their academic and social lives is grounded in the teacher's awareness of the different forces coming to bear on their classroom practices.

\section{Participants}

\section{Methods}

Six middle school mathematics teachers were used in this work to analyze the CATP instrument. The teachers ranged from 1 to 4 years of teaching experience. This group of teachers was a convenience sample from schools in which the researchers work as coaches for mathematics and literacy. All teachers were students in a special master's program designed for urban middle school teachers that included content and urban focused course work, weekly coaching by a faculty member, and a cohort system that placed teachers in schools with others in the program. The schools where the teachers work were three urban middle schools, grades 5-8, in a southeastern mid-size city (see Table 1).

Table 1

School Demographics

\begin{tabular}{|c|c|c|c|}
\hline & Washington & Buchanan & Adams \\
\hline$\%$ Asian & $6.2 \%$ & $2.0 \%$ & $4.4 \%$ \\
\hline$\%$ Black & $26.2 \%$ & $73.9 \%$ & $38.1 \%$ \\
\hline \% Hispanic & $42.0 \%$ & $8.1 \%$ & $38.3 \%$ \\
\hline$\%$ American Indian & - & - & - \\
\hline$\%$ White & $25.5 \%$ & $16.0 \%$ & $19.2 \%$ \\
\hline$\%$ Free/Reduced Lunch & $90.4 \%$ & $96.4 \%$ & $89.7 \%$ \\
\hline $\begin{array}{l}\text { \% English as a Second Language } \\
\text { Program Eligibility }\end{array}$ & $19.8 \%$ & $10.1 \%$ & $19.8 \%$ \\
\hline \% Limited English Proficiency & $25.2 \%$ & $10.5 \%$ & $23.0 \%$ \\
\hline
\end{tabular}




\section{Developing CATP}

The development of CATP involved a number of iterations of considering mathematical practices through multiple lenses. I first drew on previous work where I defined reform-oriented teaching practices (Waddell, 2010). Those practices were then compared with the current research on high leverage and ambitious practices and revised (Ball \& Forzani, 2009; Grossman, Hammerness \& McDonald, 2009; Lampert, Boerst, \& Graziani, 2011). I then amplified LadsonBillings (1994) definition of culturally relevant pedagogy with other studies on CRP in classrooms to consider how the tenets of CRP could be operationalized in mathematics classrooms. Then the revised mathematical practices were organized through the CRP lens by asking a series of questions - Which practices exemplify the ideas of supporting and developing the academic prowess of students? Which practice support opportunities for students to draw on their cultural knowledge and backgrounds as an avenue for academic success? Which practices provided opportunities to critically engage with the math content through multiple perspectives? Appendix A provides the list of practices in rubric form, defined and organized by CRP tenets.

\section{Data collection and analysis}

Each teacher was observed twice over a two-month period; each observed lesson was video recorded. The recorded lessons were chosen at the convenience of the observer and teacher from the same class period. A total of 12 videos were coded, with four videos used for training of raters. Three raters were used for this project: the principal investigator, who was also the math coach for the participants, an experienced middle school teacher who was interning with the PI in classroom coaching, and a fellow faculty member who was also a literacy coach working in urban classrooms. All raters had seven or more years of middle school teaching experience, with the PI and teacher rater having mathematics teaching experience. The raters watched four videos together to learn to use the CATP rubric; they rated the teachers' enactment of practices using a rating scale: fluent, consistent, inconsistent, or not evident (see Table 2). The raters then discussed areas of discrepancies in their ratings and what may have caused those discrepancies. After the group ratings, each rater individually rated the remaining teacher videos and those ratings were compiled and analyzed.

After the data was compiled, ratings for each teacher were tabulated, resulting in three ratings per teacher per practice. Inter-rater reliability was calculated using a linear weighted kappa between each pair of raters to determine the measure of agreement between raters; the linear weighted kappa was used 
because the ratings were related and consecutive, i.e., a rating disagreement between fluent and consistent is less troubling than the difference between fluent and inconsistent, etc. (Lowry, 2012). Additionally, the ratings for each practice were tabulated and counted to consider the levels at which the teachers enacted each practice.

Table 2

Rating descriptions for CATP

Fluent Teacher enacts practice in a natural and fluid manner; the practice is noted throughout the lesson in different areas; students respond to the practice in positive and expected ways

Consistent Teacher enacts practice in multiple ways through the lesson; students sometimes respond to the practice in expected ways

Inconsistent Teacher enacts practice minimally and/or narrowly; student response is limited and/or negligible

Not Evident The teacher does not enact the practice

\section{Findings}

To determine the agreement between raters, pair-wise ratings were counted between each pair of raters. There were 480 possible pair-wise ratings over 20 practices and 8 observed lessons. A linear-weighted kappa was calculated for each pair of raters, resulting in 3 kappa statistics: 0.3617 with standard error of 0.053 between the two faculty members, 0.2906 with standard error of 0.0675 between the PI faculty member and the teacher rater, 0.1808 with standard error of 0.07 between the second faculty member and the teacher rater. The highest value was between the two faculty members and the lowest between the teacher coder and second faculty member. Though the level of agreement as noted by the kappa statistic is low, a closer look at the actual meaning of the agreements and disagreements is warranted.

Looking at the actual ratings, $42 \%$ of all the pair-wise ratings were full agreement (F-F, C-C, etc.), and 84\% were either full agreement (both raters agreed) or one-off agreement - rater agreement is off by one category: fluentconsistent, consistent-inconsistent, inconsistent-not evident. The practices with the highest agreement by raters are noted in Table 3. Of the 20 practices, twelve had full or one-off rater agreement of $85 \%$ or better. The highest level of full agreement was $75 \%$ or 15 pair-wise ratings, with three other practices having full rater agreements of $60 \%$ and above.

Table 3

Practices with the highest rater agreement

\begin{tabular}{ccc}
\hline Practice & $\begin{array}{c}\text { Full rater } \\
\text { agreement }\end{array}$ & $\begin{array}{c}\text { Full and One-off } \\
\text { rater agreement }\end{array}$ \\
\hline Encouraging all students in their academic success; providing & $75 \%$ & $100 \%$ \\
\hline
\end{tabular}


space for accolades of academic achievement Facilitating student independent work

Demonstrating and leading students in developing respectful and caring classroom norms, individual work behaviors, habits, and attitudes through explicit critique and discussion

Using activities and tasks to encourage risk taking, perseverance, and collaborative thinking with/among students

Encouraging active listening among classroom community members by promoting and modeling student to student, student to teacher interactions

Practices with lower rater agreement are shown in Table 4. Though having one-off rater agreement of about $50 \%$, the level of full agreement was much lower for these practices, ranging from 20 to 30 percent. Of the lowest eight practices in rater agreement, the level of full rater agreement ranged from $20 \%$ to $45 \%$, but with a one-off agreement rate ranged from $55 \%$ to $80 \%$.

Table 4

Practices with low rater agreement

\begin{tabular}{lcc}
\multicolumn{1}{c}{ Practice } & $\begin{array}{c}\text { Full rater } \\
\text { agreement }\end{array}$ & $\begin{array}{c}\text { Full and One-off } \\
\text { rater agreement }\end{array}$ \\
\hline $\begin{array}{l}\text { Providing work and interaction templates, structures, routines, } \\
\text { and organizers for students in assignments, communication and } \\
\text { behaviors }\end{array}$ & $25 \%$ & $55 \%$ \\
\hline $\begin{array}{l}\text { Creating opportunities for small group/partner/collaborative } \\
\text { work }\end{array}$ & $20 \%$ & $60 \%$ \\
\hline $\begin{array}{l}\text { Using multiple forms of assessment to support the learning } \\
\text { growth of all students }\end{array}$ & $30 \%$ & $60 \%$ \\
\hline $\begin{array}{l}\text { Developing and using varied tools and representations } \\
\text { including student work }\end{array}$ & $25 \%$ & $75 \%$ \\
\hline $\begin{array}{l}\text { Modeling, comparing, and analyzing problems and solution } \\
\text { strategies with students by thinking, reasoning, and justifying }\end{array}$ & $25 \%$ & $75 \%$ \\
\hline
\end{tabular}

When considering how the raters agreed within and across CRP categories, practices that were considered cultural competence related had the highest rates of agreement ( 7 out of 7 practices had agreement of $85 \%$ or greater), while academic achievement practices had the lowest rates of agreement (only 4 out of 10 practices had agreement of $85 \%$ or greater). Critical consciousness only had three practices considered for this study, but with a rater agreement of $85 \%$ (see Table $5)$.

Table 5

Rater agreement of practices by culturally relevant pedagogy tenets

\begin{tabular}{lcc}
\hline \multicolumn{1}{c}{ CRP tenet } & Full agreement & Full and one-off agreement \\
\hline Cultural Competence & $42 \%$ & $91 \%$ \\
Critical Consciousness & $50 \%$ & $85 \%$ \\
Academic Achievement & $38 \%$ & $78 \%$ \\
\hline
\end{tabular}




\section{Discussion/Implications}

\section{Observing CATP}

The findings confirm previous research on the difficulty of operationalizing CRP. Raters had difficulty agreeing on how the practices were enacted and to what degree. It became evident during the training of CATP that the raters needed to fully develop their understanding of cultural relevance. As an example, the teacher rater had difficulty seeing practices that focused on academic achievement as being culturally relevant. Her view was that only practices that focused on issues of student culture or critical analysis of world events should be culturally relevant. Before classroom observers can work with teachers on examining and critiquing their own culturally relevant practices, the observers must also have the opportunity to do the same. When considering the importance and challenge associated with the perspective-changing elements of culturally relevant pedagogy, classroom observers need opportunities for deep learning of cultural relevance. Just as they will take their teachers through a slow, but critical shift in thinking about math learning, they too will have to look deep in themselves to consider the impact of their viewpoints and backgrounds on the work they do with teachers.

Practices with higher rater agreement correlated with practices the teachers enacted fluently or consistently. Because there was less ambiguity, it was easier for raters to discern whether the practice was enacted and to what extent. Six of the eight practices with the highest rater agreement were also the practices enacted most fluently by teachers. On the other hand, practices with low rater agreements may have occurred because a deeper understanding was needed to distinguish the degree to which a practice was enacted: What is the degree to which a practice moves from consistent to fluent? Inconsistent to consistent? This could be an issue for all ratings, but based on the data, the number of one-off ratings between fluent and consistent were the highest as compared to consistent and inconsistent, or inconsistent and not evident (see Table 6). We noted that it was more difficult to determine whether a practice was consistent or fluent due to both ratings being examples of enacting a practice well.

Table 6

Number of one-off ratings between rating categories

\begin{tabular}{lc}
\hline Ratings & Number of one off ratings \\
\hline Fluent and Consistent & 127 \\
Consistent and Inconsistent & 37 \\
Inconsistent and Not Evident & 23 \\
\hline
\end{tabular}


One explanation on the difficulty to agree on the degree to which a practice was enacted is related to the idea of what a specific mathematical practice looks like in a classroom. High level and ambitious mathematics practices move away from what many people envision a math classroom to look like - teaching topics in abstraction and context free, using deductive reasoning over intuitive (personal or invented) and empirical methods, and memorizing traditional solution methods that follow from static mathematics principles (Anderson, 1990; D' Ambrosio, 2001). Having a deep and workable vision of ambitious math practices, such as actively engaging prior content knowledge and student background knowledge or encouraging student sharing and explaining of their ideas for both correct and incorrect work/responses, is more difficult to consider without having experiences with those practices, leading to inconsistency in classroom observer ratings.

\section{Enacting CATP}

To be considered a successful implementer of CATP, a teacher had to have an overall fluent and consistent average of $80 \%$ or higher. The $80 \%$ threshold reflects having no more than 2 practices per CRP category below $80 \%$. Additionally, when ratings were categorized by CRP tenet, no tenet total should average below $80 \%$. The teacher ratings ranged from a high of $87 \%$ fluent and consistent to a low of $42 \%$. Four of the teachers would be considered successful implementers with over $80 \%$ fluent and consistent ratings. Looking at the data through percentages, we were not putting a value on a teacher's worth in the classroom. Rather, the data allowed us to recognize which areas of CRP teachers are most adept in enacting, and which areas they continue to need support.

Overall, the teachers in the study enacted the 20 CATP's fluently or consistently $74 \%$ of the time. The practices rated highest in fluency were practices around classroom community and cultural competence. For example, the teachers used math tasks that encouraged students to think together and take risks, and allowed students more opportunities to listen and communicate with each other mathematically. These practices allowed students to bring themselves into the classroom, and use their ways of communicating with supportive mediation by the teacher. Teacher leveraged student talk and representations as a bridge from informal math representations toward more formal ones. This builds a strong class community through cultural competence, by accepting and valuing shared ideas and strategies.

Practices the teachers were less successful in enacting did not fit into one CRP area. As an example, one of the lowest rated practices - analyzing and critiquing differences in world views/student life views through and with content objectives- demonstrated the teachers' continued hesitancy in delving into issues 
of social justice and questioning societal norms. Only two teachers in the study took up issues that uncovered differences or questions about the way things occurred in the world or in the classroom. It is clear that the work needed to encourage teachers to feel comfortable and confident in tackling social justice and inequality issues continues to be challenging. However, the teachers in this study were provided with opportunities to reflect on ways to engage students in these deep and important conversations. Other low rated practices reflected conflicts between expected CATP's and school norms and expectations, such as traditional classroom management protocols.

The question arises, so what does that mean? Should those teachers who are rated fluent in CATP also have higher levels of test achievement? Though student achievement levels as reflected in standardized testing are paramount to the teachers in this study, as it is for most teachers in the US, we want to measure achievement in different ways. In this study, we did not collect test data from the teachers or any other type of data that may represent the impact of successful implementation of CATP on student achievement. However, looking ahead, collecting student data on attendance, homework completion, other academic pursuits, future goal setting, and surveys on attitudes toward math and school in addition to test scores as measures of success would help more fully understanding the impact of enacting CATP.

\section{Looking Forward}

The goal for developing CATP is to allow teachers, mentors, and administrators to have a baseline of practices that reflect the ideals of developing cultural relevance in math classrooms. Having well-crafted practices that reflect the deep and critical aspects of CRP and ambitious mathematics provides starting points for conversations about classroom practices. Using such practices can help maintain and grow opportunities for critical reflection by teachers on their practices, beliefs, and cultural vision. It is the teacher's work to build a classroom environment that supports the high-level mathematical knowledge to be taught, the cultures students bring, and the practices that acknowledge, examine, and support student growth as math learners. Using a tool like CATP to consider culturally relevant pedagogy in the development of math classrooms becomes the backdrop for the rigorous work of teaching mathematics with understanding. 


\section{References}

Anderson, S.E. 1990. "Worldmath Curricula: Fighting Eurocentrism in mathematics". Journal of Negro Education. 59(3). 348-359.

Ball, D.L. 2011. "Supporting High Quality Mathematics Instruction". Presentation at the Math Intervention Leadership Summit, Austin TX. March.

Ball, D. L. and Forzani, F. 2009. The work of teaching and the challenge for teacher education. Journal of Teacher Education. 60(5). 497-511.

Ball, D.L., Sleep, L., Boerst, T., Bass, H. 2009. "Combining the Development of Practice and the Practice of Development in Teacher Education". The Elementary School Journal. 109(5). 458-474.

Benson, B. 2003. Framing Culture within classroom practice: Culturally Relevant Teaching. Action in Teacher Education. 25(2). 16-22.

Bonner, E. 2009. Achieving success with African American learners: A framework for culturally responsive mathematics teaching. Childhood Education. 86(1). 2-6.

Brenner, M. 1998. "Adding Cognition to the Formula for Culturally Relevant Instruction in Mathematics". Anthropology and Education Quarterly. 29(2). 214-244.

Burton, L. (1994). Whose culture includes mathematics? In S. Lerman (Ed.), Cultural perspectives on the mathematics classroom (pp. 68-83). Dordrecht, The Netherlands: Kluwer.

Common Core State Standards Initiative. 2010. "Common Core State Standards for Mathematics". Retrieved from: http://www.corestandards.org/assets/CCSSI_Math\%20Standards.pdf

D'Ambrosio, U. 2001. "What is Ethnomathematics, and How Can it Help Children in Schools?" Teaching Children Mathematics. 7(6). 308-310.

Enyedy, N. and Mukhopadhyay, S. 2007. They don't show nothing I didn't know: Emergent tensions between culturally relevant pedagogy and mathematics pedagogy. The Journal of the Learning Sciences. 16(2). 139-174.

Grossman, P; Hammerness, K.; McDonald, M. 2009. "Redefining teaching, reimagining teacher education". Teachers and Teaching. 15(2). 273-289.

Gutierrez, K. and Rogoff, B. 2003. "Cultural Ways of Learning: Individual traits or repertoires of practice". Educational Researcher. 32(50. 19-25.

Gutierrez, R. 2009. "Embracing the Inherent Tensions in Teaching Mathematics from an Equity Standpoint". Democracy and Education. 18(3). 9-16.

Hastie, P.; Martin, E., Buchanan, A. 2006. Stepping out of the norm: An examination of praxis for a culturally relevant pedagogy for African American children. Journal of Curriculum Studies. 38(3). 293-306. 
Hefflin, B. 2002. Learning to develop culturally relevant pedagogy: A lesson about cornrowed lives. The Urban Review. 34(3). 231-251.

Howard, T. 2001. "Telling Their Side of the Story: African-American students perceptions of culturally relevant teaching". The Urban Review. 33(2). 131-149.

Ladson-Billings, G. 1994. The Dreamkeepers: Successful Teachers of African American Children. San Francisco, CA: Jossey-Bass.

Ladson-Billings, G. 1995. "Toward a Theory of Culturally Relevant Pedagogy". American Educational Research Journal. 32(3). 465-491.

Ladson-Billings, G. 2006. "Yes, but how do we do it?". In J. Landsman and C. Lewis (eds.), White Teacher/Diverse Classrooms: A Guide to Building Inclusive Schools, Promoting High Expectations, and Eliminating Racism. Sterling, VA: Stylus Publishing. 29-42.

Lampert, M., Boerst, T., Graziani, F. 2011. " Organizational resources in the service of school-wide ambitious teaching practice". Teachers College Record. 113(7). ID: 16072. P. 1-20.

Lee, J. 1998. "State policy correlates of the achievement gap among racial and social groups". Studies in Educational Evaluation. 24(2), 137-152.

Lipman, P. 1995. "'Bringing out the best in them": The contribution of culturally relevant teachers to educational reform". Theory into Practice. 34(3). 202-208.

Lowry, R. 2012. "Kappa as a Measure of Concordance in Categorical Sorting". Retrieved from www.vassarstats.net on 10.03.12.

Matsumura, L., Slater, S., and Crosson, A. 2008. "Classroom Climate, Rigorous Instruction, and Curriculum, and Students' Interactions in Urban Middle Schools". The Elementary School Journal. 108(4). 293-312.

Matthews, L. 2003. "Babies Overboard! The complexities of incorporating culturally relevant teaching into mathematics instruction". Educational Studies in Mathematics. 53(1). 61-82.

Morrison, K., Robbins, H., Rose, Dana G. 2008. Operationalizing culturally relevant pedagogy: A synthesis of classroom based research. Equity and Excellence in Education. 41(4). 433-452.

Moses, R. and Cobb, C. 2001. "Organizing Algebra: The need to voice a demand". Social Policy. Summer. 4-12.

Mukhopadhyay, S. 2009. "Participatory and Dialogue Democracy in US Mathematics Classrooms". Democracy and Education. 18(3). 44-50.

Nasir, N. 2002. "Identity, Goals, and Learning: Mathematics in Cultural Practices". In Mathematical Thinking and Learning, 4(2\&3). Eds. N. S. Nasir and P. Cobb. Mahwah, New Jersey: Lawrence Erlbaum Associates, Publishers. 
National Council of Teachers of Mathematics. 2000. Principles and standards for school mathematics. Reston, VA. Author.

National Mathematics Advisory Panel. 2008. Foundations for Success: The Final Report of the National Mathematics Advisory Panel. U.S. Department of Education: Washington, DC.

New Oxford Dictionary. 2009. Apple, Inc.

Osisioma, I., kiluva-ndunda, m., Van Sickle, M. "Behind the Masks: Identifying students competencies for learning mathematics and science in urban settings". School Science and Math. 108(8). 389-400.

Rosa, M. and Orey, D. 2010. "Culturally Relevant Pedagogy: An ethnomathematical approach". Horizontes. 28(1). 19-31.

Roscigno, V. 1998. "Race and the reproduction of educational disadvantage". Social Forces. 76(3), 1033-1061.

Schoenfeld, A. 2002. "Making mathematics work for all children: Issues of standards, testing and equity". Educational Researcher. 31(1). 13-25.

Sleeter, C. 2010. "Confronting the Marginalization of Culturally Responsive Pedagogy". Paper presented at the Culturally Responsive Pedagogies Symposium, Hamilton, New Zealand, November.

Tate, W. 1995. "Returning to the root: A culturally relevant approach to mathematics pedagogy", Theory into Practice. 34(3). 166-173.

Tompkins, G. 2009. Language Arts: Patterns of practice. Boston, MA : Allyn \& Bacon.

Young, E. 2010. Challenges to conceptualizing and actualizing culturally relevant pedagogy: How viable is the theory in classroom practice? Journal of Teacher Education. 61(3). 248-260. 


\section{Appendix A. Culturally Ambitious Teaching Practices in Mathematics}

\begin{tabular}{|c|c|c|}
\hline \multicolumn{3}{|c|}{ CATP practice } \\
\hline \multicolumn{3}{|c|}{$\begin{array}{l}\text { Academic Achievement. The learning environment has as its focus the CRP tenet of academic achievement. Teachers } \\
\text { demand, reinforce, and produce academic excellence in their students; students' skills and abilities are valued and channeled } \\
\text { in academically important ways (Ladson-Billings, 1995). Providing structures, templates and academic protocols for students } \\
\text { allows them to have a base upon which to build their learning and in turn, will scaffold students to tackle higher-level } \\
\text { problems and tasks. Teachers also know that in order for students to be successful in the work that is expected of them, } \\
\text { additional work may be needed on a regular basis - in and out of the classroom. Students need multiple opportunities to learn } \\
\text { new materials and grapple with challenging ideas while developing perseverance and dedication for their academic } \\
\text { endeavors. This additional and focused time can allow teachers to attend to students' academic identities and explore the } \\
\text { ways those identities are tied together with their personal and cultural identities (Martin, 2000; Nasir, 2002; Nasir \& Saxe, } \\
\text { 2003). }\end{array}$} \\
\hline sub category & Academic achievement & The teacher: \\
\hline classroom interactions & $\begin{array}{l}\text { Encouraging all students in their academic } \\
\text { success; providing space for accolades of } \\
\text { academic achievement }\end{array}$ & $\begin{array}{l}\text { develops a system to provide all students with } \\
\text { academic success on their academic levels; } \\
\text { offers students consistent, focused and specific } \\
\text { feedback on their academic work; provides } \\
\text { rigorous and meaningful goals for students to } \\
\text { reach and supports all students attempts to } \\
\text { reach those goals; describes the outcomes of } \\
\text { classroom work habits and behaviors on future } \\
\text { outcomes }\end{array}$ \\
\hline $\begin{array}{l}\text { content inquiry and } \\
\text { tasks }\end{array}$ & $\begin{array}{l}\text { Questioning and probing students on multiple } \\
\text { levels (Bloom's taxonomy) and using thinking } \\
\text { time to encourage academic engagement }\end{array}$ & $\begin{array}{l}\text { Uses multiple levels of questioning (Bloom's } \\
\text { taxonomy as an example) to solicit student } \\
\text { ideas or information and probe student } \\
\text { thinking; uses multiple levels of questioning } \\
\text { and discussion with students to support } \\
\text { learning through modeling }\end{array}$ \\
\hline $\begin{array}{l}\text { content inquiry and } \\
\text { tasks }\end{array}$ & $\begin{array}{l}\text { Providing activities and tasks of a varying } \\
\text { cognitive demand that challenge all levels of } \\
\text { students in classroom - memorization, } \\
\text { procedures without connections, procedures with } \\
\text { connections, doing math. }\end{array}$ & $\begin{array}{l}\text { considers cognitive demand of work provided } \\
\text { to students; uses differentiated instruction } \\
\text { methods to allow all students to engage with } \\
\text { learning activities that encourage higher level } \\
\text { thinking }\end{array}$ \\
\hline $\begin{array}{l}\text { content inquiry and } \\
\text { tasks }\end{array}$ & $\begin{array}{l}\text { Using multiple forms of assessment to support } \\
\text { the learning growth of all students }\end{array}$ & $\begin{array}{l}\text { continually gathers information/ data about } \\
\text { students through assignments, questions, } \\
\text { interviews, writing tasks, and other means; } \\
\text { makes appropriate decisions about such } \\
\text { matters as reviewing material, reteaching a } \\
\text { difficult concept, or providing something more } \\
\text { or different for students who are struggling or } \\
\text { need enrichment; provides students with clear } \\
\text { and timely feedback on their learning with } \\
\text { opportunities for corrections and growth }\end{array}$ \\
\hline $\begin{array}{l}\text { content inquiry and } \\
\text { tasks }\end{array}$ & $\begin{array}{l}\text { Modeling, comparing, and analyzing problems } \\
\text { and solution strategies with students by } \\
\text { thinking, reasoning, and justifying }\end{array}$ & $\begin{array}{l}\text { interactively models problem solutions, games, } \\
\text { and tasks to emphasize strategies and thinking; } \\
\text { models and compares different strategies when } \\
\text { discussing student work; conjectures, } \\
\text { reasoning, error analysis, and alternative } \\
\text { solutions are discussed; models how to make } \\
\text { sense of content ideas, construct arguments, } \\
\text { analyze situations, provide evidence and } \\
\text { support for conclusions and claims }\end{array}$ \\
\hline $\begin{array}{l}\text { family, school. } \\
\text { community integration }\end{array}$ & $\begin{array}{l}\text { Creating a two way communication pathway } \\
\text { about academic progress between } \\
\text { school/classroom and families using multiple } \\
\text { forms of communication }\end{array}$ & $\begin{array}{l}\text { develops consistent forms of family } \\
\text { communications, beyond normal school } \\
\text { measures, that informs them of upcoming } \\
\text { classroom assignments, student grades, } \\
\text { conferences, and other classroom needs }\end{array}$ \\
\hline learning structure & $\begin{array}{l}\text { Providing work and interaction templates, } \\
\text { structures, routines and organizers for students } \\
\text { in assignments, communication and behaviors }\end{array}$ & $\begin{array}{l}\text { develops specific tools, routines, formats, and } \\
\text { forms to support organized learning for } \\
\text { students; provides consistent examples and } \\
\text { reminders for these structures }\end{array}$ \\
\hline
\end{tabular}




\begin{tabular}{|c|c|c|}
\hline & Cultural Competence & \\
\hline $\begin{array}{l}\text { content inquiry and } \\
\text { tasks }\end{array}$ & $\begin{array}{l}\text { Actively engaging prior content knowledge, as } \\
\text { well as student background knowledge, in } \\
\text { preparation for learning }\end{array}$ & $\begin{array}{l}\text { draws out and uses students' mathematical } \\
\text { prior knowledge as a mathematical tool; } \\
\text { considers what students may know about the } \\
\text { topic or context of the lesson and actively } \\
\text { engages students in thinking about and sharing } \\
\text { their ideas on the context; uses this information } \\
\text { to support learning of the topic; helps students } \\
\text { critique how their understandings and cultural } \\
\text { knowledge can be useful in learning }\end{array}$ \\
\hline communication & $\begin{array}{l}\text { Encouraging student sharing and explaining of } \\
\text { their ideas for both correct and incorrect } \\
\text { work/responses }\end{array}$ & $\begin{array}{l}\text { llows opportunities for sharing and explaining } \\
\text { ideas and solutions as part of classroom } \\
\text { protocols; uses student errors as teaching and } \\
\text { learning experiences; works to connect student } \\
\text { ideas to one another }\end{array}$ \\
\hline classroom interactions & $\begin{array}{l}\text { Creating opportunities for small } \\
\text { group/partner/collaborative work }\end{array}$ & $\begin{array}{l}\text { provides small group work and opportunities } \\
\text { to actively engage with task or activity; } \\
\text { encourages interdependence, accountability, } \\
\text { and participation. }\end{array}$ \\
\hline communication & $\begin{array}{l}\text { Leading whole group discussions to build } \\
\text { "taken-as-shared" understandings }\end{array}$ & $\begin{array}{l}\text { develops whole group discussions about math } \\
\text { topic of the day, providing students with } \\
\text { opportunities to engage with math ideas and } \\
\text { interact with others while doing so, uses } \\
\text { discussions to develop academic language, } \\
\text { representations, and ways of knowing that can } \\
\text { become common in the classroom }\end{array}$ \\
\hline learning structure & Facilitating student independent work & $\begin{array}{l}\text { engages with students as a support during } \\
\text { independent or small group mathematical } \\
\text { tasks; actively monitors the classroom for } \\
\text { appropriate behavior and academics focus }\end{array}$ \\
\hline communication & $\begin{array}{l}\text { Encouraging active listening among classroom } \\
\text { community members by promoting and } \\
\text { modeling student to student, student to teacher } \\
\text { interactions }\end{array}$ & $\begin{array}{l}\text { encourages students to listen, focus and } \\
\text { interact with the topic at hand and who is } \\
\text { speaking during discussion/lessons; provides } \\
\text { interaction structures for students in } \\
\text { discussions of tasks and concepts that include } \\
\text { student to student interactions }\end{array}$ \\
\hline communication & $\begin{array}{l}\text { Modeling and supporting multiple means of } \\
\text { mathematical communication using academic } \\
\text { language, everyday language, symbols and } \\
\text { representations }\end{array}$ & $\begin{array}{l}\text { encourages students to use a variety of means } \\
\text { and media to communicate and solve problems } \\
\text { in the classroom (models, drawings, symbols, } \\
\text { physical materials, verbal models, kinesthetic } \\
\text { movements); provide examples of correct usage } \\
\text { of academic language and the relationship to } \\
\text { everyday language }\end{array}$ \\
\hline $\begin{array}{l}\text { family, school. } \\
\text { community integration }\end{array}$ & Engaging in school extracurricular activities & $\begin{array}{l}\text { participates/leads extra curricular activities in } \\
\text { the school community that match personal } \\
\text { interests and skills; encourages students to join } \\
\text { activities that interest them }\end{array}$ \\
\hline $\begin{array}{l}\text { family, school. } \\
\text { community integration }\end{array}$ & $\begin{array}{l}\text { Spending time attending student social activities } \\
\text { and community projects }\end{array}$ & $\begin{array}{l}\text { attends student events that occur outside of } \\
\text { school - sporting events, recitals, church } \\
\text { services, community fairs and events - as a way } \\
\text { to understand and appreciate the community } \\
\text { and its impact on the students }\end{array}$ \\
\hline
\end{tabular}


Critical Consciousness. The idea behind critical consciousness is for students to engage the world and others critically (Ladson-Billings, 1994). However, to engage in a critical stance about learning, students need to feel safe in the classroom climate. Developing a safe classroom means teachers readily address issues and events that can potentially make students fearful and hesitant in their interactions with others. From openly sharing and analyzing mathematical mistakes to discussing the pros and cons of life pathways students' families have taken, teachers and students interrogate and dialogue school and life through a critical lens. Critical consciousness considers the inequities in society and how these inequities play out in the lives of students. For marginalized students, being able to view the world from multiple perspectives and consider how those perspectives correlate to outcomes is an important skill in the effort to mitigate the detrimental effects of having low societal status. In order to consider and understand the ways in which societal biases impact policies, rules, and structures, students will need to develop a critical or problematic stance for trying to uncover such biases. A problematic stance means you consider things from a critical or questioning point of view (Hiebert et al., 1997). This problematic stance, however, does not only have to be used when thinking of issues in society and community. This also includes ideas such as basic algorithms in math as well as reasons for war in social studies. Asking why we learn certain algorithms or whose viewpoints the reasons for war are supported and whose viewpoints are rejected denote viewing school learning in a problematic way. Developing a problematic stance in relation to everyday school learning is important, as it develops the skill of critical inquiry in students that includes querying issues and ideas both in and out of school.

\begin{tabular}{|c|c|c|}
\hline & Critical Consciousness & \\
\hline $\begin{array}{l}\text { content inquiry and } \\
\text { tasks }\end{array}$ & $\begin{array}{l}\text { Analyzing and critiquing differences in world } \\
\text { views/student life views through and with } \\
\text { content objectives }\end{array}$ & $\begin{array}{l}\text { researches and analyzes school content from } \\
\text { multiple perspectives; provides avenues for } \\
\text { students to engage in a critical analysis and } \\
\text { evaluation of content; makes connections to the } \\
\text { world and student communities through } \\
\text { mathematical discussions and activities; } \\
\text { interacts with school community outside of } \\
\text { classroom as a way to gain access to relevant } \\
\text { connections }\end{array}$ \\
\hline $\begin{array}{l}\text { family, school. } \\
\text { community integration }\end{array}$ & $\begin{array}{l}\text { Supporting families' understanding of } \\
\text { connection among school requirements, student } \\
\text { needs/future goals, family habits }\end{array}$ & $\begin{array}{l}\text { develops and maintains regular interactions } \\
\text { with families to inform them of upcoming } \\
\text { events, avenues for academic support, how up } \\
\text { coming events impact students' academic lives; } \\
\text { pathways toward family/student desired } \\
\text { academic goals }\end{array}$ \\
\hline classroom interactions & $\begin{array}{l}\text { Demonstrating and leading students in } \\
\text { developing respectful and caring classroom } \\
\text { norms, individual work behaviors, habits, and } \\
\text { attitudes through explicit critique and discussion }\end{array}$ & $\begin{array}{l}\text { requires students to demonstrate respectful, } \\
\text { caring, and supportive behavior to one another } \\
\text { while demonstrating that same behavior to all } \\
\text { classroom members; consistently and quickly } \\
\text { addresses issues of disrespect as a model for } \\
\text { classroom behavior; builds a classroom } \\
\text { community that works to establish } \\
\text { participation norms through critique and } \\
\text { discussion; considers differences between } \\
\text { school and home behaviors and openly } \\
\text { discusses them }\end{array}$ \\
\hline
\end{tabular}

